
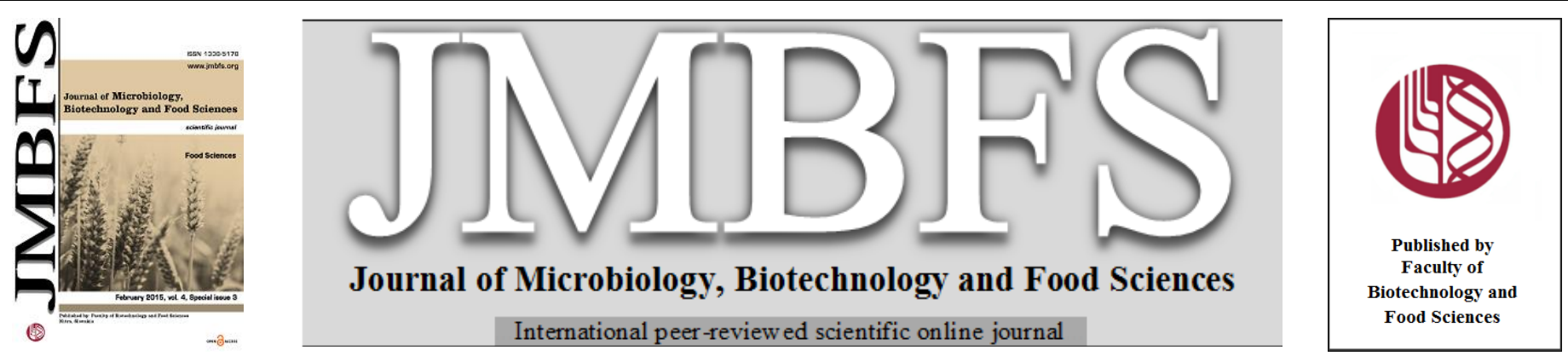

\title{
MINERALS, MICROELEMENTS AND POLYPHENOLS CONTENT IN THE SOYBEAN VARIETIES GROWN IN DIFFERENT LOCALITIES OF SLOVAKIA
}

\section{Mária Timoracká*, Ján Tomáš, Alena Vollmannová, Pavol Trebichalský, Luboš Harangozo}

Address(es): Ing. Mária Timoracká, PhD.

Slovak University of Agriculture in Nitra, Faculty of Biotechnology and Food Sciences, Department of Chemistry, Tr. A. Hlinku 2, 94901 Nitra, Slovak Republic, phone number: +421376414862.

*Corresponding author: maria.timoracka@uniag.sk

doi: 10.15414/jmbfs.2015.4.special3.152-156

\section{ART ICLE INFO}

Received 27. 11.2014

Revised 3. 12. 2014

Accepted 4. 12. 2014

Published 2. 2. 2015

$\frac{\overline{\text { Regular article }}}{{ }_{\text {OPEN }} \bigodot_{\text {ACCESS }}}$

\begin{abstract}
The aim of this study was to evaluate the influence of the grown locality on minerals and risky metal intake from the soil an $\mathrm{d}$ on polyphenols formation in the soybean seeds. The research was realised in five localities of Slovakia using the seven soybean varieties. From the point of the soil hygiene, all determined values of heavy metals content in soils were lower than given hygienic limits, with the exception of Cd. Minerals and heavy metals contents in the soybean samples show significant differences between cultivars and localities. The values show imbalance between the potassium contents and other minerals. The order of the elements levels was determined as following: $\mathrm{Fe}>\mathrm{Zn}>\mathrm{Mn}>\mathrm{Cu}>\mathrm{Ni}>\mathrm{Pb}>\mathrm{Cr} \approx \mathrm{Co}>\mathrm{Cd}$. The risk y elements contents, with exception of $\mathrm{Cd}, \mathrm{Cu}, \mathrm{Pb}$ and $\mathrm{Ni}$ content (only in some localities), did not exceed a limit for legumes by Food Codex SR. The total polyphenols content ranged from 817.6 to $1281.0 \mu \mathrm{g}$ eq. tannic acid/g and suggest the variety dependence, but the locality influence was not significantly confirmed.
\end{abstract}

Keywords: Soybean, heavy metals, minerals, polyphenols, locality

\section{INTRODUCTION}

Soyfoods have become increasingly popular among interested health individuals over the past 10-15 years. Several large food companies offer now marketing soy products, such as breakfast cereals and energy bars. Therefore, consumers have even greater access to a wide variety of soy foods, which will likely result in a further mainstreaming of soy products (Messina, 1999). Nowadays, they are being studied for their potential role in the prevention and treatment of a number of chronic diseases including certain forms of cancer, osteoporosis, and heart disease, and also for their ability to relieve menopausal woman symptoms. Soybean is a unique source of polyphenols components called phytoestrogens which include a wide variety of plant products with weak estogenic activity (Franke et al., 1994). Polyphenols are biologically active metabolites that accumulate in soybean during its development. The amount of polyphenols present in soybean is variable, also depending on genetic and environmental factors (the type of cultivar, and growth location can influence on the polyphenols formation).

Soybean is also rich and inexpensive source of proteins, carbohydrates, dietary fibres to millions of peoples. In addition to being an important source of protein, legumes are also reported to be a good source of minerals $(\mathrm{K}, \mathrm{P}, \mathrm{Ca}, \mathrm{Mg})$ and trace elements. Metals, such as iron, zinc and manganese are essential metals, since they play an important role in biological systems. $\mathrm{Cu}$ and $\mathrm{Zn}$ are essential micronutrients, they can be toxic when taken in excess. Lead and cadmium are nonessential metals as they are toxic, even in trace (Gençcelepet al., 2009). The monit oring of heavy metals content in soybean is very important because its consumption shows an increasing tendency.

Therefore the aim of this study was to determine the contents of mineral elements, trace elements, and total polyphenols in the seven varieties of cultivated raw soybeans (Glycine max L.) - cvs. Bolyi-45, Supra, Korada, Belmont, Crystal, Erin, Quito and to evaluate the relationship of these components of soybean grown at five different localities of Slovakia (Malacky, Oponice, Jelšovce, Marcelová, Belá nad Cirochou).

\section{MATERIALS AND METHODS}

Plant material. Soybean (Glycine max. L.) seeds were purchased in cooperation with the farms so that they represented a significant area of that crop in Slovakia. Company PRIVATEX-Agro Company Ltd. New Locks supplied soybean variety Bolyi-45, Erin, Korada, Supra and Quito, which were grown in the area Marcelová. The varieties Crystal and Belmont delivered by Jelšovce and also varieties Korada and Supra were from Oponice. The Korada variety was also grown in the area of Belá nad Cirochou and Malacky. The seeds were manual cleaned a stored in paper sacks in normal st orage conditions for further analysis. Soils samples. Collection of soil samples was performed from the same plots, which were collected the tested crop. Sampling and adjustment of soil samples followed the "Binding methodologies of soils analysis" (Fiala et al., 1999). Soi samples were taken from the soil science probe depths of 0 to $0.1 \mathrm{~m}$. The location of delivery points of soybean and soil samples is indicated on the map of Slovakia (Figure 1).

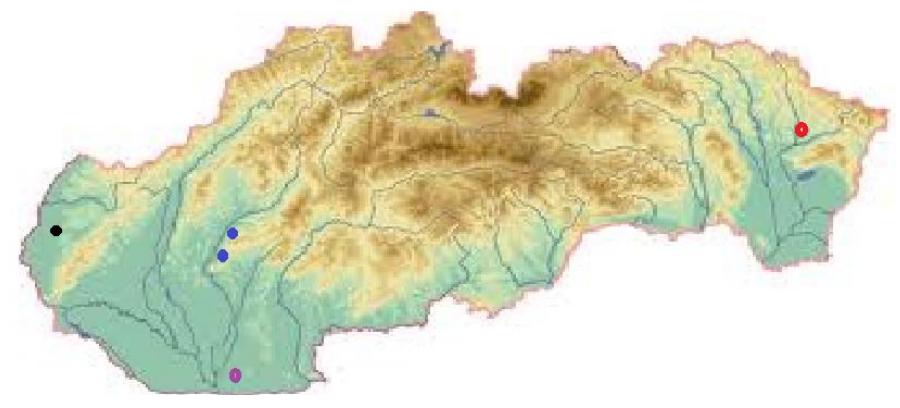

Figure 1 Location of delivery points of soybean and soil samples black point - Malacky, violet point - Marcelová, blue point - Nitra area (Jelšovce, Oponice), red point - Belá nad Cirochou

Analytical methods. Major mineral elements (K, $\mathrm{Ca}, \mathrm{Mg})$ and trace elements $(\mathrm{Fe}$, $\mathrm{Mn}, \mathrm{Zn}, \mathrm{Cu}, \mathrm{Co}, \mathrm{Ni}, \mathrm{Cr}, \mathrm{Pb}, \mathrm{Cd}, \mathrm{Na}$ ) were determined using a Varian AA240FS at omic absorption spectrometer equipped with a $\mathrm{D} 2$ lamp background correction system, using an air-acetylene flame. Phosphorus was measured by a colorimetric method using tartate antimonylo-potassium and molybdate ammmonium reagent. Nitrogen was determined by the Kjeldhal method. Soil. Nutrients contents (K, Ca, Mg, P) were determined by Mehlich II. procedure and the total and releasable contents of risk elements were determined using $\mathrm{HF}+\mathrm{HNO}_{3}$ solution and the solution of $2 \mathrm{M} \mathrm{HNO}_{3}$, respectively. 
Seeds. Between 0.9 and $1.1 \mathrm{~g}$ of dried sample was weighed into digestion tubes and $\mathrm{HNO}_{3}$ were added. The samples were incinerated in a Nabertherm muffle furnace. Ashes were dissolved in nitric acid and passed through an ash-free, acidwashed filter paper and diluted to a certain volume with water.

Minerals and microelements concentrations were determined on a dry weight basis as $\mu \mathrm{g} / \mathrm{g}$. The results were evaluated according to the Decision of Ministry of Agriculture in Slovak republic about highest acceptable limits of toxic compounds in soil No. 531/1994 - 540 and Food Codex of the Slovak Republic.

Total polyphenols. The total polyphenols content were determined by the method of Lachman et al., (2003) and expressed in $\mu$ geq. tannic acid per g dry matter. Statistics. Results were processed by using Statistica $6.0 \mathrm{Cz}$ software. Dat a were expressed as average values \pm standard deviation of six replications. Significant differences between varieties, and growth localities were tested by Tukey-test at the significance level $p<0.05$ (elements) or at $p<0.01$ (polyphenols).

\section{RESULTS AND DISCUSSION}

\section{Soil hygiene evaluation}

The necessity to monitor the soil elements content is especially important from the aspect of food safety and quality assurance, because the soil as a starting place for input of risk compounds into a human chain. The soil reaction has a major effect on the intake of many risky elements; the most of them become more available to plants as $\mathrm{pH}$ decreases.

As shown in Table 1 , in the locality Marcelová soil reaction value $\left(\mathrm{pH}_{\mathrm{KC}}\right)$ varied in the range from 5.01 to 7.55. From this wide range of values shows that soils are slightly acidic to alkaline. Other interest localities had neutral (Jelšovce, Oponice) to acid (Malacky, Belá nad Cirochou) soil reaction. In the soils of observed areas was a reserve of humus on medium level, except Malacky, which had a good reserve of hummus. The levels of available nutrients in the studied soils were variable. Magnesium content ranged from low (Belá nad Cirochou) through high (Marcelová, Malacky) to very high level (Oponice); potassium from low (Belá nad Cirochou) through medium (Malacky) to good level (Oponice, Marcelová); phosphorus from medium (Belá nad Cirochou, Oponice) through good (Malacky) to very high level (Marcelová).

Table 1 Available nutrients content in $\mu \mathrm{g} / \mathrm{g}$, soil reaction and humus content (\%) in soils of different sites of soybean cultivation

\begin{tabular}{|c|c|c|c|c|c|c|c|c|c|}
\hline locality & & site (variety) & $\mathbf{C a}$ & Mg & $\mathbf{K}$ & $\mathbf{P}$ & $\mathbf{N}$ & рНкса & hummus \\
\hline \multirow{5}{*}{\multicolumn{2}{|c|}{$\begin{array}{l}\stackrel{-\pi}{2} \\
\frac{0}{0} \\
\stackrel{0}{J} \\
\stackrel{J}{\Sigma}\end{array}$}} & MČ-3 (Supra) & 851 & 153 & 269 & 74.3 & 1050 & 5.1 & 2.79 \\
\hline & & Markacová (Quito) & 4440 & 148 & 225 & 62.6 & 1487 & 7.3 & 2.44 \\
\hline & & Pri Virte (Erin) & 6280 & 173 & 148 & 44.4 & 1312 & 7.46 & 2.35 \\
\hline & & $\begin{array}{l}\text { Dolnožitavská } \\
\text { (Korada) }\end{array}$ & 1909 & 287 & 207 & 144.4 & 1400 & 6.88 & 2.25 \\
\hline & & Ármaiho (Bolyi45) & 4155 & 99 & 97 & 33.4 & 875 & 7.55 & 1.52 \\
\hline Jelšovce & & (Crystal, Belmont) & 2930 & 265 & 266 & 82.1 & 1575 & 7.11 & 2.51 \\
\hline Oponice & & (Supra, Korada) & 3950 & 314 & 296 & 45.7 & 962 & 7.10 & 2.32 \\
\hline $\begin{array}{l}\text { Belá } \\
\text { Cirochou }\end{array}$ & nad & Štaň (Korada) & 978 & 86 & 107 & 55.1 & 1575 & 5.51 & 2.64 \\
\hline Malacky & & Prostredná (Korada) & 2455 & 251 & 135 & 76.9 & 1750 & 5.12 & 3.27 \\
\hline
\end{tabular}

In the tables 2 and 3 are the results of the determination of heavy metals in soils of interest sites. Gained result s were evaluated according to the valid legislatives. The values of total risk elements contents (Table 2) were under the limits defined the limit value A with the exception of $\mathrm{Cd}$ (because its total contents were enhanced on all plots). In the soil from the localities Oponice, Jelšovce were exceeded also values of background limit $\mathrm{A}$ for $\mathrm{Ni}$ and $\mathrm{Cu}$. The determined $\mathrm{Cd}$, $\mathrm{Cu}, \mathrm{Ni}$ content exceeded the limit values A (from 4,7 to $25,9 \%, 2,7 \%, 2,7 \%$, respectively), but in neither case it reached the indicative limit values $\mathrm{B}$ established by legislative for soil contamination. However, from the point of view of risky metal intake by plants, is important content of accessible, respectively potentially mobile forms of heavy metals. In table 3 contents of mobile forms of selected heavy metals in soil ex tract by $2 \mathrm{M} \mathrm{HNO}_{3}$ are presented. All of determined values were lower than reference value $A_{1}$ again with the exception of $\mathrm{Cd}$ (a background value $\mathrm{A}_{1}$ for $\mathrm{Cd}$ is $0,3 \mu \mathrm{g} / \mathrm{g}$ ). The heavy metals contents in soil did not exceeded the limit values specified by Law 531/1994 540 (Decision of the Ministry of Agriculture SR, 1994). And from this perspective soil can be described as relatively uncontaminated.

Table 2 Total content of heavy elements ( $\mu \mathrm{g} / \mathrm{g}$ ) in soils of different sites of soybean cultivation

\begin{tabular}{|c|c|c|c|c|c|c|c|c|}
\hline locality & site (variety) & $\mathbf{Z n}$ & $\mathrm{Cu}$ & $\mathrm{Cr}$ & Cd & $\mathbf{P b}$ & $\mathbf{N i}$ & Co \\
\hline \multirow{5}{*}{ 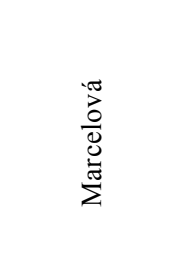 } & MČ-3 (Supra) & 55.2 & 28.4 & 39.6 & 0.72 & 22.4 & 26.4 & 13.2 \\
\hline & Markacová (Quito) & 53.2 & 22.4 & 45.2 & 0.92 & 24.0 & 28.0 & 14.0 \\
\hline & Pri Virte (Erin) & 47.2 & 20.0 & 42.0 & 0.84 & 23.6 & 28.4 & 14.4 \\
\hline & $\begin{array}{l}\text { Dolnožitavská } \\
\text { (Korada) }\end{array}$ & 61.6 & 24.8 & 50.8 & 0.88 & 26.0 & 30.0 & 13.6 \\
\hline & Ármaiho (Bolyi45) & 41.2 & 16.8 & 34.8 & 0.84 & 23.2 & 23.2 & 12.0 \\
\hline Jelšovce & (Crystal,Belmont) & 78.8 & 36.8 & 57.6 & 1.00 & 28.8 & 34.4 & 17.2 \\
\hline Oponice & (Supra, Korada) & 95.2 & 37.2 & 60.0 & 1.8 & 31.6 & 36.0 & 17.2 \\
\hline $\begin{array}{l}\text { Belá nad } \\
\text { Cirochou }\end{array}$ & Štaň (Korada) & 55.6 & 21.6 & 51.2 & 0.72 & 25.2 & 20.4 & 11.6 \\
\hline Malacky & Prostredná (Korada) & 63.2 & 30.0 & 64.8 & 0.92 & 28.4 & 31.2 & 12.0 \\
\hline Limit value $\mathrm{A}^{*}$ & & 140 & 36 & 130 & 0.8 & 35 & 35 & 20 \\
\hline
\end{tabular}

A* - background value by The Decision of Ministry of Agriculture of Slovak Republic about highest acceptable limits of toxic compounds in soil No. 531/1994-540. Thehigher values of elements than is maximal allowed level given by the valid legislative are printed in bold. 
Table 3 Risky elements content $(\mu \mathrm{g} / \mathrm{g})$ in $2 \mathrm{M} \mathrm{HNO}_{3}$ extract in soils of different sites of soybean cultivation

\begin{tabular}{|c|c|c|c|c|c|c|c|c|}
\hline locality & site (variety) & $\mathbf{Z n}$ & $\mathbf{C u}$ & $\mathrm{Cr}$ & Cd & $\mathbf{P b}$ & $\mathbf{N i}$ & Co \\
\hline \multirow{5}{*}{ 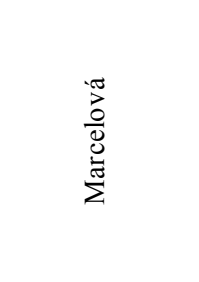 } & MČ-3 (Supra) & 5.8 & 8.3 & 1.2 & 0.16 & 6.8 & 5.1 & 1.7 \\
\hline & Markacová (Quito) & 6.2 & 7.6 & 1.9 & 0.29 & 8.3 & 5.9 & 3.8 \\
\hline & Pri Virte (Erin) & 5.0 & 6.9 & 1.9 & 0.38 & 7.7 & 5.7 & 3.9 \\
\hline & $\begin{array}{l}\text { Dolnožitavská } \\
\text { (Korada) }\end{array}$ & 9.5 & 8.3 & 2.0 & 0.21 & 7.9 & 5.5 & 2.9 \\
\hline & Ármaiho (Bolyi45) & 4.3 & 5.7 & 1.4 & 0.26 & 6.1 & 3.7 & 2.7 \\
\hline Jelšovce & (Crystal,Belmont) & 10.1 & 11.3 & 2.1 & 0.29 & 11.1 & 6.5 & 4.4 \\
\hline Oponice & (Supra, Korada) & 17.3 & 9.8 & 2.4 & 0.34 & 14.9 & 4.6 & 4.2 \\
\hline $\begin{array}{l}\text { Belá nad } \\
\text { Cirochou }\end{array}$ & Štaň (Korada) & 7.9 & 4.4 & 2.1 & 0.23 & 10.9 & 1.7 & 2.2 \\
\hline Malacky & Prostredná (Korada) & 10.5 & 8.6 & 3.4 & 0.21 & 8.8 & 6.4 & 2.0 \\
\hline Reference valu & $\mathrm{e} \mathrm{A}_{1} *$ & 40 & 20 & 10 & 0.3 & 30 & 10 & $\mathrm{x}$ \\
\hline
\end{tabular}

A $\mathrm{A}_{1}$ - background value in $2 \mathrm{MHNO}_{3}$ extract by The Decision of Ministry of Agriculture of Slovak Republic about highest acceptable limits of toxic compounds in soil No. 531/1994 - 540. The higher values of elements than is maximal allowed level given by the valid legislative are printed in bold.

Nutrients and microelements content in soybean seeds

In this study, the existence of five abudant minerals was (inclusive nitrogen) determined in soybean samples (Table 4). The potassium content was found to be higher than those of other minerals in all soybeans, followed by $\mathrm{P}, \mathrm{Mg}, \mathrm{Ca}$, which contents varied in the ranges $4350-8431 \mathrm{mg} / \mathrm{g}, 1895-2363 \mathrm{mg} / \mathrm{g}, 739-1173$ $\mathrm{mg} / \mathrm{g}$, respectively. The values show imbalancebetween the potassium content and other components. On the other hand, high potassium content in the diet contributes to regulation of water and salt balance in organism and the ratio $\mathrm{Na}$ : $\mathrm{K}$ is adequate for human nutrition. The mean $\mathrm{Ca}: \mathrm{P}$ ratio in soybeans, being $\approx$ 0.15 , reveals a high concentration of phosphorus compared to calcium. This ratio should not be less than 1.0 (Iqbal et al.,2006). Mineral supplementation can be used as an alternative approach to correct this imbalance. The contents of $\mathrm{K}$ and
$\mathrm{P}$ are higher than the others $(\mathrm{Ca}, \mathrm{Mg}, \mathrm{Fe})$, and the order from high to low does not change with the producing area. Producting area does not affect the contents of elements $\mathrm{K}, \mathrm{P}$ and $\mathrm{Mg}$ significantly $(\mathrm{P}<0.05)$. It can be concluded that the demands for major mineral elements $\mathrm{K}, \mathrm{P}$ and $\mathrm{Mg}$ are relative stable in the growth of soybeans with the same variety. Calcium values are lower than those in the literature (Campos-Vega et al., 2010; Wan et al., 2010). The Mg, K, P levels are adequate. Kjeldahl-N was determined and crude protein content in seeds was calculated by the factor 6,25 . On the basis results, protein content in bean seeds is between 33.1 - 35.5\% which corresponds with a data by Vojtaššáková $\boldsymbol{e t ~ a l . , ~}$ (1999). The results show that soybeans are rich in mineral elements that human body needs.

Table 4 Minerals content $(\mathrm{mg} / \mathrm{g})$, protein content (\%) and dry mater (\%) in soybean samples

\begin{tabular}{|c|c|c|c|c|c|c|c|}
\hline locality & variety & $\mathbf{C a}$ & Mg & $\mathbf{K}$ & $\mathbf{P}$ & protein & DM \\
\hline \multirow{5}{*}{$\begin{array}{l}\frac{\pi}{3} \\
\frac{0}{0} \\
0 \\
\tilde{J} \\
\Sigma\end{array}$} & Bolyi-45 & 863 & 2009 & 19607 & 7094 & 34.5 & 95.1 \\
\hline & Erin & 860 & 2227 & 20724 & 6570 & 33.7 & 94.7 \\
\hline & Korada & 848 & 2019 & 19955 & 7495 & 34.1 & 94.3 \\
\hline & Quito & 1061 & 1895 & 18400 & 5167 & 34.4 & 94.7 \\
\hline & Supra & 915 & 2363 & 19705 & 6102 & 34.1 & 95.0 \\
\hline \multirow{2}{*}{ Jelšovce } & Crystal & 964 & 2174 & 19807 & 7219 & 33.2 & 95.6 \\
\hline & Belmont & 1173 & 2017 & 18253 & 4350 & 33.9 & 96.6 \\
\hline \multirow{2}{*}{ Oponice } & Supra & 996 & 2326 & 21890 & 7390 & 33.1 & 95.2 \\
\hline & Korada & 832 & 2190 & 21557 & 7143 & 35.5 & 95.4 \\
\hline $\begin{array}{l}\text { Belá nad } \\
\text { Cirochou }\end{array}$ & Korada & 910 & 2145 & 21165 & 8431 & 34.7 & 94.4 \\
\hline Malacky & Korada & 739 & 1981 & 22777 & 7201 & 34.1 & 94.8 \\
\hline
\end{tabular}

Table 5 Heavy metals content $(\mu \mathrm{g} / \mathrm{g})$ in soybean samples

\begin{tabular}{|c|c|c|c|c|c|c|c|c|c|c|c|}
\hline locality & variety & $\mathrm{Fe}$ & Mn & $\mathbf{Z n}$ & $\mathrm{Cu}$ & Co & $\mathbf{N i}$ & $\mathrm{Cr}$ & $\mathbf{P b}$ & Cd & $\mathrm{Na}$ \\
\hline \multirow{5}{*}{$\begin{array}{l}-\pi \\
0 \\
0 \\
0 \\
0 \\
\tilde{J} \\
\Sigma\end{array}$} & Bolyi45 & 107 & 22.4 & 41.4 & 15.5 & 0.7 & 7.2 & 0.4 & 0.9 & 0.19 & 7.9 \\
\hline & Erin & 130 & 20.7 & 38.0 & 13.8 & 0.7 & 5.6 & 0.9 & 1.1 & 0.23 & nd \\
\hline & Korada & 100 & 24.3 & 31.4 & 11.9 & 0.5 & 4.7 & 0.5 & 0.5 & 0.24 & 4.8 \\
\hline & Quito & 111 & 21.0 & 35.9 & 12.6 & 0.4 & 3.6 & 0.5 & 0.8 & 0.36 & 10.6 \\
\hline & Supra & 138 & 25.3 & 41.5 & 14.6 & 0.7 & 5.8 & 0.4 & 1.1 & 0.27 & nd \\
\hline \multirow{2}{*}{ Jelšovce } & Crystal & 126 & 24.7 & 47.1 & 13.9 & 0.8 & 8.2 & 0.6 & 0.7 & 0.26 & 1.2 \\
\hline & Belmont & 192 & 23.3 & 41.1 & 12.4 & 0.6 & 7.2 & 0.7 & 0.8 & 0.19 & 7.1 \\
\hline
\end{tabular}




\begin{tabular}{|c|c|c|c|c|c|c|c|c|c|c|c|}
\hline \multirow{2}{*}{ Oponice } & Supra & 80 & 19.5 & 51.8 & 19.7 & 0.5 & 3.9 & 0.4 & 0.9 & 0.22 & 12.2 \\
\hline & Korada & 91 & 20.7 & 52.1 & 21.1 & 0.5 & 3.6 & 0.6 & 1.0 & 0.23 & 16.3 \\
\hline $\begin{array}{l}\text { Belá nad } \\
\text { Cirochou }\end{array}$ & Korada & 117 & 26.4 & 46.9 & 16.7 & 0.7 & 4.7 & 0.7 & 0.9 & 0.41 & nd \\
\hline Malacky & Korada & 130 & 21.1 & 46.3 & 15.5 & 0.5 & 13.1 & 0.7 & 0.8 & 0.26 & nd \\
\hline
\end{tabular}

nd- not detected

The Food Codex of the Slovak Republic has set a limit for the maximum levels of chosen risk elements in legumes; for cadmium, lead, chromium, copper and nickel are maximum values $0.1 ; 1.0 ; 4.0 ; 15.0 ; 6.0 \mu \mathrm{g} / \mathrm{g}$, respectively. The higher values of elements than is maximal allowed level given by the valid legislative are printed in bold.

Heavy metals accumulation in plants depends upon plant species, and the efficiency of different plants in absorbing metals is evaluated by either plant uptake or soil to plant transfer factors of the metals (Rattan et al., 2005). The content of selected heavy metals is shown in Table 5. The order of the elements levels in all tested soybean seeds was determined as following: $\mathrm{Fe}>\mathrm{Zn}>\mathrm{Mn}>$ $\mathrm{Cu}>\mathrm{Ni}>\mathrm{Pb}>\mathrm{Cr} \approx \mathrm{Co}>\mathrm{Cd}$. The levels of essential elements (Fe, $\mathrm{Zn}$ ) in these legumes were higher than those of toxic elements $(\mathrm{Pb}, \mathrm{Cd})$. The order from high to low for iron, zinc, nickel, and copper varied with the producing area, while at least variable elements were manganese, chromium, lead, cobalt and cadmium contents $(\mathrm{P}<0.05)$. It means, that the producing area has a great influence on the contents of above elements in soybean $(\mathrm{P}<0.05)$.

Legumes are known as zinc accumulators (Genccelep et al., 2009) and zinc concentrations of our tested legume ranged from 31.4 to $52.1 \mu \mathrm{g} / \mathrm{g}$. The minimum and maximum zinc levels were found in the same variety of soybean (Korada) from different localities. The content of $\mathrm{Zn}$ had a medium positive correlation with that of $\mathrm{Cu}, \mathrm{Pb}, \mathrm{Mg}, \mathrm{K}$ and no significant negative correlation with that of Fe and $\mathrm{Mn}$. Manganese was found to be relatively high, its content in samples were between 19.5 and $26.4 \mu \mathrm{g} / \mathrm{g}$. The highest manganese concentrations were found in the variety Korada. The most abundant element from heavy metals group, was found to be iron (ranging from 80.4 to $192.8 \mu \mathrm{g} / \mathrm{g}$ ).

Any of the determination of heavy metals content in the soil below the threshold does not guarantee that the plants growing on this soil will always contain their tolerable amounts. It is therefore crucial in terms of hygiene, whether the heavy metals accumulate in parts of plant used for consumption (Rattan et al., 2005). Our result s confirmed the ability of soybeans to accumulate contents of risky metals such as $\mathrm{Cd}, \mathrm{Pb}, \mathrm{Ni}$, and $\mathrm{Cu}$. Only chromium and cobalt concentrations, accumulated in soybeans samples, were $0.4-0.9 \mu \mathrm{g} / \mathrm{g}, 0.4-0.8 \mu \mathrm{g} / \mathrm{g}$, respectively, which did not pose a health risk. Chromium is considered to be essential to a part of the living organism, but in increased concentration is toxic. The legislative value given by Food Codex of the Slovak Republic for $\mathrm{Cd}$ content in foodstuffs determined in the samples of soybeans was in all sampling plots exceeded. The enhancement was in interval $100-300 \%$ above the maxima available value. Soybean samples also contained higher amounts of lead, copper and nickel in some growing localities. The determined $\mathrm{Pb}$ content in two plots in
Marcelová locality was slightly exceed hygienic limit value. The determined $\mathrm{Cu}$ and $\mathrm{Ni}$ contents in some localities (but represented by the all parts of Slovakia) was by $1-70 \%$ and $20-116 \%$, respectively, higher than hygienic limit value given by Food Codex of the Slovak Republic. As shown in Table 5, mainly in the Nitra region (Oponice and Jelšovce localities) and Malacky region was exceeded values of $\mathrm{Ni}$ or $\mathrm{Cu}$ content with bioavialibility of different varieties of soyben samples.

Influence of environmental conditions on the amount of heavy metals were tested in two soybean varieties (Supra, Korada) grown in different regions of Slovakia. The variety Korada from three different localities (Oponice, Belá nad Cirochou, and Malacky) was contained higher amount of copper in than those same variety from Marcelová locality. The similar situation was observed also in zinc content Zinc results showed higher accumulation of this element in the same localities and both $\mathrm{Zn}$ and $\mathrm{Cu}$ showed the positive correlation in tested sample of variety Korada. Copper can be found in many enzymes, some of which are essential for Fe metabolism and there are probable direct correlation between the dietary $\mathrm{Zn}$ and $\mathrm{Cu}$ ratio and the incidence of cardiovascular disease (Campos-Vega $\boldsymbol{e t}$ al. 2010). Based on the results obtained in the variety Supra we can state higher content of monitored elements: $\mathrm{Cd}, \mathrm{Pb}$ (Marcelová) and $\mathrm{Cu}$ (Oponice). Generally, these varieties have been an accumulat or of chosen monitored elements.

Despite of low concentration of $\mathrm{Pb}, \mathrm{Ni}, \mathrm{Cu}$ and also $\mathrm{Cd}$ in analysed soil samples from all sampling sites, soybean s can accumulate also dangerous amount of these heavy metals. The results confirm the potencial risk of environmental pollution sourced influence on the food raw materials safety. It is necessary to monitor the heavy metal content in the soils as well as in the agricultural plants grown in observed localities because of food chain safety assurance.

\section{Total polyphenols content in soybean samples}

At the same time in the soybean samples were evaluated the polyphenol contents in the dependence on a variety, properties and type of soil in observed areas. Results of total polyphenols determination (expressed as $\mu \mathrm{g}$ eq. tannic acid per $g$ of DW) assayed in the soybean varieties grown in different localities of Slovakia are presented in Table 6 .

Table 6 Polyphenols content ( $\mu \mathrm{g} / \mathrm{g})$ in soybean samples grown in different localities in Slovakia

\begin{tabular}{lll}
\hline \hline locality & variety & polyphenols content \\
\hline \hline Marcelová & Bolyi-45 & $993.4 \pm 1.5^{\mathrm{e}}$ \\
& Erin & $835.7 \pm 1.2^{\mathrm{a}}$ \\
& Korada & $828.7 \pm 2.5^{\mathrm{a}}$ \\
& Quito & $1281.0 \pm 2.2^{\mathrm{f}}$ \\
Jelšovce & Supra & $877.2^{\mathrm{a}} \pm 2.2^{\mathrm{a}, \mathrm{b}}$ \\
\cline { 2 - 3 } & Crystal & $883.8 \pm 2.8^{\mathrm{a}, \mathrm{b}, \mathrm{c}}$ \\
Oponice & Belmont & $817.6 \pm 2.1^{\mathrm{a}}$ \\
\cline { 2 - 3 } & Supra & $910.0 \pm 1.5^{\mathrm{b}, \mathrm{c}, \mathrm{d}}$ \\
Belá nad Cirochou & Korada & $943.0 \pm 1.3^{\mathrm{b}, \mathrm{c}, \mathrm{d}, \mathrm{e}}$ \\
\cline { 2 - 3 } Malacky & Korada & $944.4 \pm 1.4^{\mathrm{c}, \mathrm{d}, \mathrm{e}}$ \\
\cline { 2 - 3 } & Korada & $950.1 \pm 4.1^{\mathrm{d}, \mathrm{e}}$ \\
\hline \hline
\end{tabular}

Values in the column with different letters present significant differences at $p<0.01$

Individual localities of soybean cultivation did not significantly differ in an altitude or a weather conditions, but the differences have been shown in soil quality. Influence of environmental conditions on the amount of polyphenolic compounds were tested in two soybean varieties (Supra, Korada) grown in different regions of Slovakia (Oponice, Marcelová, Malacky, Belá nad Cirochou). As shown in Table 6, at the significance level $\alpha=0.01$ was not unequivocally confirmed the expected statistically significant impact of locality on total polyphenol content in soybean seeds.
The values of the total polyphenols content of the variety Supra between the localities Oponice and Marcelová were comparable. In the tested soybean variety Korada the measured values of total polyphenols differed bet ween the localities, but the differences were not statistically significant, with the exception of the variety grown in Marcelová soil, which obtained the lowest polyphenols content $(828.7 \mu \mathrm{g} / \mathrm{g})$ not only between the localities, but also between the varieties grown in this area (Marcelová). The order of localities for the total polyphenols content in the variety Korada is as follows: Marcelová $<$ Oponice $<$ Belá nad Cirochou $<$ Malacky. 
Lachmanet al., (2006) found on the based obtained results after the application of different fertilization variants on different crop species, that higher doses of potassium or magnesium were cause of lower accumulation of total polyphenolic compounds in tested agricultural crops. Even in our case, was observed an interesting tendency in lower polyphenols content in different soybean varieties in localities with good to high contents of some nutrients $(\mathrm{Mg}, \mathrm{K})$ and higher contents of risk elements (Jelšovce, Oponice, Marcelová-Dolnožitavská).

The soybean variety Korada with the lowest polyphenols content among the varieties grown in Marceloválocality, was grown on the site (Dolnožitavská), which is characterized by high contents of nutrients and good soil reaction $\left(\mathrm{pH}_{\mathrm{KC}}\right.$ $=6.88$ ) for the cultivation of soybeans compared to other parcels of that area. In the consistency with this trend is also the established amount in the variety Korada grown in the locality with low contents of $\mathrm{Mg}$ and $\mathrm{K}$ and an acid soil reaction (Belá nad Cirochou), indicating a potential negative correlation bet ween the polyphenols content and the available nutrients in the soil. Contrary with this hypothesis is the highest determined value of polyphenols content in the variety Korada from Malacky locality, which is characterized a high content of $\mathrm{Mg}$ and middle values of $P$ and $K$ contents.

The explanation for the higher content might be stress conditions (increasing mobility of heavy metals in the soil and transfer to plant) caused by the an acid soil reaction of this area. It is a paradox, the Supra variety grown in soil with a very high content of magnesium and a neutral soil reaction (Oponice locality) was contained inconclusive $(\mathrm{P}<0.01)$ higher amounts of polyphenols than the same variet y from locality with medium content of magnesium and a slightly acidic reaction (plot MC-3, Marcelová locality). The soils of both regions are characterized by a good to medium content of potassium and phosphorus. Significant differences were also found bet ween varieties Quito, Erin, Bolyi-45 grown on plots with alkaline soil reaction (Marcelová locality). Soils from parcels of Marcelová locality were characterized by medium to good content of potassium and magnesium, medium to very high contents of phosphorus, with the except Ármaiho plot, on which they were detected low levels of available nut rients (except Ca) and humus. This site at the same time was characterized by the highest value of a soil reaction $\left(\mathrm{pH}_{\mathrm{KCl}}=7.55\right)$ of all plots in monitored locality. In the variety Bolyi-45 grown on the plot (Ármaiho) was determined on average about $17.3 \%$ higher total polyphenols content compared with polyphenols content in other varieties (with the except of the variety Quito). In connection with the above, we can conclude that "rougher" agronomic conditions for growing soybeans are condition for an increased production of polyphenols. In contrast, it is again interesting to note that the variety Quito grown in soils with a good nutrient content (Markacová plot) had the highest content of polyphenols $(1281.0 \mu \mathrm{g} / \mathrm{g})$ among the varieties grown in the Marcelová locality and at the same time the highest levels of polyphenols in the all tested varieties soybeans in all studied localities.

Influence of the locality on the total polyphenols content was also determined by the evaluation the interactions between early (Erin, Korada) and late (Crystal, Belmont, Bolyi-45) varieties of soybeans. A significant differences $(\mathrm{P}<0.01)$ were observed between Bolyi-45 - Erin, Bolyi-45 - Korada (Marcelová) Belmont - Korada varieties. The late varieties Belmont, Crystal, cultivated in soil with good nutrient content $(\mathrm{K}, \mathrm{Mg}, \mathrm{P}, \mathrm{N})$ and by a suitable soil reaction (Jelšovce), had significantly $(\mathrm{P}<0.01)$ lower the total poylphenols level than the late variety Bolyi- 45 of the mentioned site Ármaiho (Marcelová). The difference in the total polypphenols amount bet ween early cultivars Erin and Korada grown in the same locality (Marcelová) was minimal, but the Erin cultivar had the total polyphenols content on average $11.6 \%$ lower in comparison with Korada grown in all other interest areas. The analogy in the relation to locality of soybean cultivation reached after the evaluation the results of polyphenols obtained in the late variety Belmont and the early variety Korada. Although the obt ained results again suggest the influence of locality, a contradictory interpretation of significant total polyphenols results of the late varieties Bolyi-45 and Belmont in the relation to the variety Korada indicates to the varietal determination, which the most showed in the above-mentioned Marcelová locality $(\mathrm{P}<0.01)$. By comparison the determined total polyphenols values in Table 6 in soybean cultivars grown in the Marcelová locality was found considerable variability of values in the range from 828.7 to $1281.0 \mu \mathrm{g} / \mathrm{g}$. The variety Quito was characterized by the highest total polyphenols content and the lowest contents of heavy metals as stress factor, and in comparison with Korada cultivar had 1.5fold higher polyphenols content. On the basis of this results can be created the following order of varieties grown in Marcelová: Quito $>$ Bolyi-45> Supra $>$ Erin $>$ Korada. Comparison of a soil quality in individual sites of this locality and the total polyphenols content in soybean seeds suggests an association between the nutrient content, risk elements and formation of polyphenols in soybean.

\section{CONCLUSION}

Soybean proved to be a good source of many minerals and elements. Minerals or heavy metals contents show significant differences between cultivars and localities. The potassium content was found to be higher than those of other minerals in all soybeans, followed by $\mathrm{P}, \mathrm{Mg}, \mathrm{Ca}$, which contents varied in the ranges $4.35-8.43 \mathrm{mg} / \mathrm{g}, 1.89-2.36 \mathrm{mg} / \mathrm{g}, 0.74-1.17 \mathrm{mg} / \mathrm{g}$, dw, respectively. The values show imbalance between the potassium content and other components, but the ratio $\mathrm{K}: \mathrm{Na}$, and $\mathrm{Ca}: \mathrm{P}$ is adequate for human nutrition. The order of the elements levels in all tested soybean seeds was determined as following: $\mathrm{Fe}>\mathrm{Zn}>\mathrm{Mn}>\mathrm{Cu}>\mathrm{Ni}>\mathrm{Pb}>\mathrm{Cr} \approx \mathrm{Co}>\mathrm{Cd}$. The risky elements contents, with the exception of cadmium and cuprum (only cv. Korada grown in three localities) and $\mathrm{Ni}$ content in varieties Crystal, Belmont grown in Jelšovce), did not exceed a limit for the maximum levels of chosen risk elements in legumes.

At the same time, the total polyphenols contents were determined: their concentrations were found to range from 817.65 to 1281.00 ( $\mu \mathrm{g}$ tannic $\mathrm{acid} / \mathrm{g}$ ). From quantitative analysis polyphenols, the gained results suggest the variety dependence, but the locality influence on these compounds forming was not significantly confirmed, but results both indicate that the formation of polyphenols is probably genetically determined.

Acknowledgement: The work was supported by grant VEGA No. 1/0724/12 and No. 1/0308/14 from Ministry of Education, Slovak Republic.

\section{REFERENCES}

CAMPOS-VEGA，R., LOARCA-PIÑA，G., OOMAH，D.B. 2010. Minor components of pulses and their potencial impact on human health. Food Research International, 43,461-482. http://dx.doi.org/ 10.1016/j.foodres.2009.09.004 DECISION OF THE MINISTRY OF AGRICULTURE IN SLOVAK REPUBLIC No. 531/1994-540 about highest acceptable limits of toxic compounds in soil. MP SR: vol. XXVI, $\mathrm{I}^{\text {st }}$ part., $3^{\text {rd }}$ decision, No. 531/1994. FIALA K. et al. 1999. Binding methods of analysis of soils. Partial monitoring system - soil. Bratislava : VÚPOP, p. 142.

FRANKE, A.A., CUSTER, L.J., CERNA, C.M., NARALA, K.K. 1994. Quantitation of phytoestrogens in legumes by HPLC. Journal of A griculture and Food Chemistry, 42, 1905-1913. http://dx.doi.org/ 10.1021/jf00045a015.

FOOD CODEX OF THE SLOVAK REPUBLIC. 2004. No 608/3/2004 - 100 GENOVESE, M.I., HASSIMOTTO, N.M.A., LAJOLO, F.M. 2005. Isoflavone profile and antioxidant activity of brazilian soybean varieties. Food Science and Technology International, 11, 205-211. http://dx.doi.org/ $10.1177 / 1082013205054499$.

GENÇCELEP. H., UZUN, Y., TUNÇTÜRK, Y., DEMIREL, K. 2009 Determination of mineral content of wild-grown edible mushrooms. Food Chem istry, 133, 1033-1036. http://dx.doi.org/ 10.1016/j.foodchem.2008.08.058.

IQBAL, A., KHALIL, I.A., ATEEQ, N., KHAN, M.S. 2006. Nutritional quality of important food legumes. Food Chemistry, 97, 331-335. http://dx.doi.org/ 10.1016/j.foodchem.2005.05.011

LACHMAN, J., HAMOUZ, K., ĆEPL, J., PIVEC, V., ŠULC, M., DVOŘÁK, P. 2006. Influence of chosen factors on the total polyphenols content and antioxidant activity in potato tubers. Chemické listy, 100, 522-527.

LACHMAN, J., HEJTMÁNKOVÁ, A., DUDJAK, E., FERNÁNDEZ, E.C., PIVEC, V. 2003. Content polyphenolic antioxidants and phenolcarboxylic acids in selected parts of yacon. Vitamins. Pardubice : University Pardubice, 89-97. MESSINA, M.J. 1999. Legumes and soybeans: overview of their nutritional profiles and health effects. American Journal of Clinical Nutrition, 70, 439S450S.

RATT AN, R.K., DATTA, S.P., CHHONKAR, P.K., SURIBABU, K., SINGH, A.K. 2005. Long-term impact of irrigation with sewage effluents on heavy metal content in soils, crops and groundwater - a case study. Agriculture, Ecosystem and Environment, 109, 310-322. http://dx.doi.org/ 10.1016/j.agee.2005.02.025. VOJT AŠŠÁKOVÁ, A., KOVÁČIKOVÁ, E., SIMONOVÁ, E., HOLČÍKOVÁ, K. 1999. Cerals and legumes - food tables. Bratislava : VÚP, $265 \mathrm{p}$.

WAN, J., LIU, CH.-M., LIU, W., TU, Y.-C., LI, CH., ZHANG, W.-Q. 2010 Determination of mineral elements in soybean from different producing areas by ICP-AES. Research Gate, 30, 543-545. 